DOI: 10.20472/AHC.2019.005.001

\author{
SIRIWAN ANANTHO \\ Center for Communication Policy Study, Thailand
}

\title{
A 10-YEAR DESCRIPTIVE ANALYSIS OF MEDIA MANAGEMENT RESEARCH
}

\begin{abstract}
:
Media management is a multidisciplinary approach that requires various kinds of knowledge including media studies, management, economics, politics and social science. The increasing development of communication technology has seriously affected people's lifestyle and consumers' behavior. Government policies and guidelines have been revised to keep up with changing environment of media industry. Media managers and operators need to adjust themselves and look for new strategies to survive in high competitive market. The educational institutions also inevitably need to adapt themselves in order to cope with the new social context and market demand. This researcher conducted a descriptive study on media management research published from 2008 to 2017. The research objectives were to synthesize significant themes, theoretical concepts, and research methods in the area of media management.

The research explored international database of thesis/dissertation, as well as international academic articles on media management. Using mixed methods approach, the data were analyzed using descriptive statistics and qualitative content analysis. The results of the research showed that the topics related to media management appeared more in doctoral dissertation than in master's theses. Additionally more media management articles were published in Journal of Media Business Studies (JOMBS) than other journals included in the study. The type of media most found in theses/dissertation database were new media, television and newspaper respectively, while television and newspaper were most found in articles published in selected journals. News was the most important area of media management study in both theses/dissertation database and academic journals. During 10 years time frame, most media management research used qualitative method, followed by quantitative and mixed methods respectively, and the theories employed were diverse and often integrated. Most research was conducted in the United States, only a few were from other countries, such as China, UK, India, Canada, France etc. The results of this study might be useful for media professionals and academics for future analysis and planning in media management.
\end{abstract}

\section{Keywords:}

media management, descriptive analysis, mixed method. 